Article

\title{
"Indigenizing" Food Sovereignty. Revitalizing Indigenous Food Practices and Ecological Knowledges in Canada and the United States
}

\author{
Charlotte Coté \\ Department of American Indian Studies, University of Washington, Seattle, WA 98195, USA; clotise@uw.edu \\ Academic Editors: Karen L Thornber and Tom Havens \\ Received: 30 November 2015; Accepted: 5 January 2016; Published: 15 July 2016
}

\begin{abstract}
The food sovereignty movement initiated in 1996 by a transnational organization of peasants, La Via Campesina, representing 148 organizations from 69 countries, became central to self-determination and decolonial mobilization embodied by Indigenous peoples throughout the world. Utilizing the framework of decolonization and sustainable self-determination, this article analyzes the concept of food sovereignty to articulate an understanding of its potential for action in revitalizing Indigenous food practices and ecological knowledge in the United States and Canada. The food sovereignty movement challenged the hegemony of the globalized, neoliberal, industrial, capital-intensive, corporate-led model of agriculture that created destructive economic policies that marginalized small-scale farmers, removed them from their land, and forced them into the global market economy as wage laborers. Framed within a larger rights discourse, the food sovereignty movement called for the right of all peoples to healthy and culturally appropriate food and the right to define their own food and agricultural systems. "Indigenizing" food sovereignty moves beyond a rights based discourse by emphasizing the cultural responsibilities and relationships Indigenous peoples have with their environment and the efforts being made by Indigenous communities to restore these relationships through the revitalization of Indigenous foods and ecological knowledge systems as they assert control over their own foods and practices.
\end{abstract}

Keywords: Indigenous; decolonization; food sovereignty; sustainable self-determination; colonization; globalization; ecological knowledge; colonialism

Children, language, lands; almost everything was stripped away, stolen when you weren't looking because you were trying to stay alive. In the face of such loss, one thing our people could not surrender was the meaning of land. In the settler mind, land was property, real estate, capital, or natural resources. But to our people, it was everything: identity, the connection to our ancestors, the home of our nonhuman kinfolk, our pharmacy, our library, the source of all that sustained us. Our lands were where our responsibility to the world was enacted, sacred ground. It belonged to itself; it was a gift, not a commodity, so it could never be bought or sold ([1], p. 17).

In Braiding Sweetgrass, Indigenous botanist Robin Kimmerer summons readers to imagine a different relationship with the land, water, plants, and animals; to rebuild a sustainable relationship where people and the land are good medicine for each other; to open minds and hearts to the gifts they provide, which will be returned in a circle of reciprocity. She writes,

In the indigenous worldview, a healthy landscape is understood to be whole and generous enough to be able to sustain its partners. It engages land not as a machine but as a community of respected non-human persons to whom we humans have a responsibility...reconnecting people and the landscape is as essential as reestablishing proper hydrology or cleaning up contaminants. It is medicine for the earth ([1], p. 338). 
Indigenous peoples globally are actively shaping, nurturing and fostering healthy and sustainable communities through their self-determination efforts and decolonization strategies. The decolonial praxis entails decreasing dependence on the globalized food system and revitalizing Indigenous foods systems and practices through the reaffirmation of spiritual, emotional and physical relationships to the lands, waters, plants, and all living things that have sustained Indigenous communities and cultures.

The food sovereignty movement initiated in 1996 by a transnational organization of peasants, La Via Campesina, representing 148 organizations from 69 countries, called for the right of all peoples to healthy and culturally appropriate food and the right to define their own food and agricultural systems. Framing its position within a larger "rights" based discourse, the movement challenged the hegemony of the globalized, neoliberal, industrial, capital-intensive, corporate-led model of agriculture that created destructive economic policies that marginalized small-scale farmers, removed them from their land, and forced them into the global market economy as wage laborers [2-8]. The movement quickly became central to self-determination and decolonial mobilization embodied by Indigenous peoples throughout the world.

"Indigenizing" the food sovereignty movement means moving it beyond the rights based discourse to emphasize cultural responsibilities and relationships that Indigenous peoples have with their environment. It also requires examining the efforts being made by Indigenous communities to restore these relationships through the revitalization of their Indigenous foods and ecological knowledge systems as they assert control over their own wellbeing. Utilizing the framework of decolonization and sustainable self-determination, this article first discusses the impacts of colonialism and historical trauma on Indigenous peoples and cultures and then identifies recent Indigenous mobilization and resurgence, which includes efforts to revitalize traditional food systems and practices. The concept of food sovereignty is then explored in an attempt to articulate an understanding of its potential for action in revitalizing Indigenous food practices and ecological knowledge in the United States and Canada. I end with a discussion on the Nuu-chah-nulth in Canada who have taken responsibility of revitalizing and restoring their sacred relationship with their ancestral homelands by creating environmental and food policies grounded in traditional principles.

\section{Colonialism and Historical Trauma}

Indigenous peoples and communities globally have experienced a series of traumatic invasions that have had long-lasting and disastrous outcomes. Massacres, genocidal policies, disease pandemics, forced removal and relocation, Indian boarding school assimilation policies, and prohibition of spiritual and cultural practices have produced a history of ethnic and cultural genocide. In "Historical Trauma in American Indian/Native Alaska Communities", Indigenous scholar Teresa Evans-Campbell characterizes the effects of U.S. colonialism on Native Americans as cumulative intergenerational trauma, whereby they suffer from the highest rates of interpersonal violence, child abuse and neglect, poor health, negative stereotypes and microaggressions that denigrate and destabilize their societies and identity and adversely affect individual and community physical, social, psychological, emotional and spiritual health and wellbeing ([9], p. 316).

Many of the health issues and inequalities Indigenous peoples face today can be directly linked to colonization, the brutal dispossession of homelands, globalization, migration, and culture and language loss. U.S. and Canadian policies legalized this cultural assault that was further intensified by socioeconomic and political marginalization along with racial prejudice, which, too, was often institutionalized ([10], p. 66).

In analyzing colonialism and historical trauma, readers cannot overlook the disturbing legacy of the federal Indian boarding school policy and the horrific impact it had on Indigenous identity and culture. By the late 1800s, both Canada and the United States had adopted an educational system of boarding schools (also called residential schools in Canada) whereby Indigenous youth between the ages of five and 15 were taken from their families and communities and placed in these institutions 
designed specifically and intentionally to eradicate their spiritual traditions, political and economic systems, languages, and cultures.

Richard Henry Pratt, the founder of the first off-reservation boarding school in the U.S., the Carlisle Indian School, which opened 1 November 1879, created an educational system built on the rapid and absolute assimilation of Indigenous children into Euro-American society, which required complete rejection of their own cultural and spiritual beliefs. Pratt's philosophy for creating these schools was clearly evident in his statement that became the motto for the U.S. boarding school system: "Kill the Indian...Save the Man" ([11], p. 52). Duncan Campbell Scott, Canadian superintendent general for Indian Affairs, made it quite clear the intent of a 1920 law that made it compulsory for all Indigenous children in Canada to attend boarding (residential) schools: "Our object is not to quit until there is not one Indian left that has not been absorbed into the body politic" ([12], p. 51).

Under this U.S and Canadian policy framework of forced cultural assimilation and within a Euro-American/Canadian value system that encouraged individualism, competition, and a belief in Christian faith, Indigenous children were severed from their families, their communities, their homelands, and their traditional foods. Indigenous identity to a large extent is a collective identity, and the experiences of the generations of children who attended these schools resulted in collective trauma framed within a context of loss-loss of family, community, language, culture, and innocence through the rampant physical, psychological, emotional, and sexual abuse these children suffered in these institutions ([13], pp. 76-78).

Many scholars have written about the unspeakable abuses that Indigenous children suffered in these schools, and in the last 20 years, Indigenous peoples have shared stories of trauma as a way to heal the pain and reconcile with the past [11,14-17]. On 2 June 2008, Canada established the Truth and Reconciliation Commission to address the appalling legacy of Canada's boarding (residential) school system and to provide a forum for former boarding school "survivors" and families to come together in dialogue, support and healing [18]. On June 11 of the same year, Canada's Prime Minister Stephen Harper publically apologized for the government's administration of these schools calling it "a sad chapter in our history" and emphasizing how "this policy has had a lasting and damaging impact on Aboriginal culture, heritage and language" through "the emotional, physical and sexual abuse and neglect of helpless children, and their separation from powerless families and communities" [19].

In these schools, Indigenous children were forced to eat foods that many had never eaten before, foods such as domesticated meats, cheese, wheat flour, and sugar, and were estranged from their own traditional and healthy diets. Nuu-chah-nulth elder Trudy Frank sees a direct correlation to the major health issues facing members of her community and the foods they were forced to eat in boarding school. Frank's narrative elucidates the racism the young Indigenous students faced when they attempted to eat their traditional foods. She writes,

When we got to residential school we were supposed to eat what was put in front of us. And it was none of our type of food. They'd make fun of us if we wanted to have some boiled fish heads or something like that. They used to call us savages because we ate all this...natural foods. If we were hungry [for traditional foods] they used to say, "Oh, the savage in you is coming out." You know, we learned to eat processed food, we learned to eat sweetened food. So, we had no choice in what we had to eat ([12], p. 194).

While boarding school narratives have elucidated the horrors of these schools and how Indigenous children were fed inadequate and unhealthy diets, it was not until 2013 that the extent of nutrition deficiency was revealed. In May 2013, Canadian food scholar Ian Mosby exposed more of the horrors of the Canadian Indian Residential School system, revealing how secret nutritional experiments had been conducted on malnourished Indigenous children in boarding schools, thus illuminating the exploitation and neglect by the Canadian government of the Indigenous population.

These experiments arose from other studies being conducted on Indigenous peoples at the same time to analyze and provide a solution to why these communities were experiencing extreme 
social and health problems that were to a much higher degree than the larger Canadian population. The commonly held misconception at this time, which arose out of racially stereotyped views of Indigenous peoples, was that the social dysfunction, poverty, high mortality rates, and serious health issues Indigenous communities were experiencing stemmed from inherited traits in their flawed cultures. A 1946 study, published in the Canadian Medical Association Journal, moved the focus away from these inferior culture arguments and linked these social and health problems to inadequate and unhealthy food. The report revealed:

It is not unlikely that many characteristics, such as shiftlessness, indolence, improvidence and inertia, so long regarded as inherent or hereditary traits in the Indian race may, at the root, be really the manifestations of malnutrition. Furthermore, it is highly probable that their great susceptibility to many diseases, paramount amongst which is tuberculosis, may be directly attributable to their high degree of malnutrition arising from the lack of proper foods ([20], p. 146).

These kinds of reports led to a series of intensive multi-year studies of Indigenous communities throughout Canada by leading nutritionists such as Dr. Frederick Tisdall, the co-inventor of the infant food Pablum, in cooperation with the Department of Indian Affairs and the Indian Health Services Branch of the Department of National Health and Welfare. In fall 1948, the researchers turned their attention to Canada's Indian Residential Schools, conducting tests over a five-year period at six residential schools across the nation with close to 1000 Indigenous children selected for the experiments. These research investigations were conducted by trained dietitians working for either the Red Cross or the federal Nutrition Division led by director Lionel Pett ([20], pp. 146, 161).

One of the schools included in this study was the Alberni Indian Residential School in British Columbia, opened in 1890 and run by the Presbyterian Church until it burned down in 1917. The Canadian government reopened it in 1920 and in 1925 handed over administration to the United Church, which operated the school until it shut down in 1973. The Alberni Indian Residential School was built in the middle of my community on lands that were removed from the federal lands that were set aside for my people following colonization. By the 1950s Indigenous children throughout Canada were being phased into the public school system and many of the children who attended this school were brought here from rural Indigenous communities. The school loomed like a dark haunting beast on top of a hill, and I remember as a young girl staring through the chain link fence watching all the young Indigenous boys and girls, wondering why they were locked up in this dark and dismal place.

Investigations of the Alberni Residential School found run-down, inadequate kitchen facilities and, as was the case with the other schools included in the study, poor and inadequate diets given to the students. As part of the study, some of the children's diets were enhanced with Western food products such as milk and fruit, along with vitamin supplements, while other children in the study were given nothing or placebos ([20], pp. 161-62).

The studies identified a major dietary issue in Indigenous communities, that the levels of malnutrition were directly linked to increasing dependence on "store foods," which were highly processed foods mainly consisting of white flour, lard, and sugar and making up 85 percent of their diet while they were forced away from their more nutritious traditional foods consisting of fish, wild game, and berries. However, rather than develop policies that would support the revitalization of Indigenous food systems or provide them with healthy traditional foods, the dietitians conducting the studies sought to address these problems by promoting what they saw as more nutritious Western foods like milk, cheese, and fruit ([20], p. 155).

Never was it revealed that in order to conduct these studies, most of these children were continually fed nutritionally inadequate diets, sometimes up to five years, knowingly keeping them underfed and denying them healthy foods as well as certain types of dental care. Mosby argues that these experiments exposed "the systematic neglect and mistreatment of students in these schools," making these institutions into ideal scientific test centers "providing access to a population of 
chronically malnourished and vulnerable children who, as wards of the state, had little say in whether or not they participated in the study" ([20], pp. 162, 165). What Mosby found even more disturbing was that these food experiments were being conducted without the children's knowledge and without their parent's consent.

Nuu-chah-nulth elder Benson Nookemus attended the Alberni Indian Residential School from 1942 to 1947. While he does not know if he was one of the children who were unwittingly part of the food experiments, his narrative illustrates the constant state of starvation these children were experiencing while the studies were being conducted. Before being taken from his home and placed in the Alberni Residential School, Nookemus's daily diet consisted of traditional foods such as salmon and shellfish, foods he never received at the school. His memories of attending the school are narratives of hunger and sickness. He writes how the children would get one bowl of porridge in the morning and one piece of stale bread in the afternoon. The school had a vegetable garden that the children cultivated, but they were not allowed to eat these foods, which went to the people who worked there. Nookemus says, "We'd get so hungry, we'd steal potatoes and eat them raw...it seemed like some of us were always sick" [21]. On discovering that he attended a school that was part of these food experiments and that he could have been one of the children purposely starved for this study, Nookemus says, "I feel angry" [21]. After leaving the school, Nookemus' dental health began to deteriorate and he eventually lost all of his teeth [21].

While the postwar world was becoming more socially conscious of using humans to conduct biomedical experiments and in the wake of the establishment of the Nuremberg Code of experimental research ethics, in Canada, Mosby argues, Indigenous bodies were being used as "experimental materials," and the residential schools and Indigenous communities became "laboratories" that those conducting the experiments could use to pursue their own political and professional agendas ([20], p. 148).

While the tragic legacy of the boarding system had a disastrous impact on Indigenous peoples dietary as well as emotional and spiritual wellbeing, socioeconomic status also plays a major role in Indigenous health disparities along with the loss or dislocation from their traditional lands and communities (more than 50 percent of Indigenous peoples in Canada and the U.S. live in urban centers) and the inability to access their traditional foods as a result of forced migration, urbanization and environmental contamination. A growing epidemic of lifestyle disease is occurring among Indigenous peoples such as type 2 diabetes mellitus, cardiovascular disease, hypertension, autoimmune disease, and obesity. While these diseases are increasing in the larger U.S, and Canadian populations, they have become more prevalent in Indigenous populations. For example, recent studies have shown that Indigenous adults are four times more likely to suffer from type 2 diabetes than the non-Indigenous population ([22,23]; [10], p. 70; [13], p. 72).

Type 2 diabetes leads to other illnesses and health concerns, such as cardiovascular disease, kidney failure, blindness, lower-extremity amputation, disability, and a decreased quality of life. The risk of developing type-2 diabetes increases with obesity and physical inactivity, which is not only a concern for adults but children as well, with recent studies revealing serious youth obesity problems in Indigenous communities leading to major health issues such as type 2 diabetes and heart disease as they age ([23]; [24], p. 1487; [12], pp. 193-97).

For Indigenous peoples, the colonial narrative has resulted in social, cultural, and economic marginalization and is reflected in the health disparities with non-Indigenous peoples in the larger Canadian and U.S. populations. Diseases such as type-2 diabetes, hypertension, and obesity are at epidemic levels, making autonomy over Indigenous lands and food systems crucial to their very survival as people.

\section{Indigenous Resistance and Resurgence}

The approximately 350 million Indigenous peoples worldwide share a collective experience of colonization that is still being felt in their communities today. The very definition of "Indigenousness", 
Taiaiake Alfred and Jeff Corntassel assert, "is an identity constructed, shaped and lived in the politicized context of contemporary colonialism" ([25], pp. 597-98).

The challenge of "being Indigenous", in a psychic and cultural sense, forms the crucial question facing Indigenous peoples today in the era of contemporary colonialism—a form of post-modern imperialism in which domination is still the Settler imperative...Contemporary Settlers follow the mandate provided for them by their imperial forefathers' colonial legacy, not by attempting to eradicate the physical signs of Indigenous peoples as human bodies, but by trying to eradicate their existence as peoples through the erasure of the histories and geographies that provide the foundation for indigenous cultural identities and sense of self ([25], p. 598).

Using Franz Fanon's notion of unity in Indigenous resistance, Alfred and Corntassel describe how colonial powers actively and aggressively attempt to disrupt and erase the Indigenous sense of place and community and replace these with "doctrines of individualism and predatory capitalism," sometimes successfully. They cite the contemporary treaty process in British Columbia, Canada, and tribal gaming in the United States as examples of co-optation and forced federalism ([25], p. 608; [26]). Indigenous peoples, Alfred and Corntassel maintain, need to create physical and psychological spaces that are resistant to the negative grip and influences of imperialism and globalization in what Feliciano Sanchez Chan defines as "zones of refuge" ([25], p. 605).

Decolonization is central to "unraveling the long history of colonization" ([27], p. 71). As Indigenous scholar Angela Cavender Wilson asserts, it entails a reaffirmation of Indigenous epistemological and ontological foundations that colonial forces have worked to silence in what Maori scholar Linda Tuhiwai Smith describes as "the struggle for decolonization" ([28], p. 201). "[D]ecolonization offers a strategy for empowerment", says Cree scholar Winona Wheeler and through auto-criticism and self-reflection Indigenous peoples can develop a critical consciousness about how colonization has impacted their lives and then move beyond this oppression by restoring health to their communities through re-engagement of their traditions ([27], p. 71).

Recent mobilization seen in the 1994 Zapatista uprising in Chiapas Mexico, the signing of the United Nations Declaration on Indigenous Rights (UNDRIP) in 2007, and the emergence of the Canadian Idle No More Movement in 2012, builds on ongoing Indigenous resistance to colonialism, neoliberalism, and globalization and the disastrous impacts these systems continue to have on ancestral homelands. Fundamental to these recent struggles are the goal of self-determination and the commitment to protecting Indigenous lands from exploitation and development. The UNDRIP, adopted by the United Nations in 2007, enshrined global Indigenous collective rights that constituted the minimum standards for their survival, dignity, and well-being. Among the rights recognized were the right to self-determination, the right to self-government, and the right to lands and resources that Indigenous peoples traditionally owned or occupied [29]. While the UNDRIP is an aspirational, nonbinding document, some countries such as the Philippines and Bolivia have adopted the document's provisions as law, and Indigenous groups globally have begun testing the enforcement of these provisions ([30], p. 156).

Kristin Moe asserts that the Zapatista's, more than any other Indigenous movement, have successfully linked "local issues of cultural marginalization, racism, and inequality" to global threats of neoliberal economic policies exemplified by the North American Free Trade Agreement (NAFTA) and the World Trade Organization (WTO), and to the growing danger of human-induced climate change ([31], pp. 31-32). Both the Zapatista Movement and the Idle No More Movement in Canada effectively utilized social media to bring awareness to Indigenous land rights and environmental issues. Idle No More was founded in December 2012 by three Indigenous women and one non-Indigenous woman mainly in response to the passing of Canada's Bill C-45 which eliminated many of the state's environmental laws and opened up Indigenous lands to development. 
Idle No More's core vision centers on a call of unity to bring Indigenous and non-Indigenous peoples together in a "peaceful revolution" that honors Indigenous sovereignty and works to protect the land and water [32]. It quickly spread to include opposition to Canada's Tar Sands oil energy project and the expansion of oil pipelines across Canada and the United States. The movement is rooted in ancestral knowledge and the understanding that it is our moral duty to protect the water and land for the future generations. As Terry Wotherspoon and John Hansen assert, Idle No More marked "the re-awakening of an Indigenous tradition and culture grounded in respect for the environment, fostering resistance to the kinds of exploitation of land and water conveyed through many of the terms of Bill C-45" ([33], p. 23).

\section{Globalization and Neoliberal Food Production}

The last 30 years have seen an increase in the globalization of food systems through neo-liberal state policies that placed decision-making authority over food production and distribution in the hands of national states, and supranational and transnational organizations, promoting agricultural and food practices that did little to alleviate world hunger. The over-commodification of food after World War Two resulted in concentrating the decision-making power over food, land, and seeds in the hands of only a few, and developing policies that regulated food to meet the demands of the agribusiness industry. This neo-colonial process impoverished millions of peasants and Indigenous peoples by displacing them from the land, resulting in many of them being forced into wage labor to serve the global food economy [2-7].

Indigenous peoples have recognized the dangers of a worldview that commodifies and de-sanctifies the earth. Harnessed by colonial policies that restricted Indigenous response, their ancestors watched the destruction and rape of their lands and cultures unfold. Dependence on the global food economy threatened Indigenous food systems and practices and as Indigenous scholar Waziyatawin asserts, "this disconnect was key to the process of colonization" and "[c]olonial governments worked systematically to break our ancestors' connections to our homelands" ([34], p. 72). It is for these reasons, Waziyatawin asserts, that it is imperative that Indigenous people must vigorously defend and restore their sacred relationships to their homelands through what she defines as a feedback loop.

A feedback loop is also embedded here; the more we learn to restore local food practices, the more likely we are to defend those practices, and the stronger our cultural ties to our homeland become. If we choose this course of action, we can simultaneously engage both the resurgence and resistance elements of a decolonization movement. Our survival will depend on it ([34], p. 74).

In 1993, small-scale farmer's organizations formed La Via Campesina, and, since then, this global agrarian movement has become the strongest voice in radical opposition to the globalized, neoliberal model of agricultural food production. In a conference held in 1996 in Tlaxcala, Mexico, La Via Campesina criticized the state led food security movement to end global hunger, which focused on access for all people to sufficient, safe and nutritious foods to meet their dietary needs. This food security program, La Via Campesina asserted, did little to address the real issue: control over food production and distribution. They also emphasized that the current regime continued to promote agricultural practices that benefitted transnational corporations while undermining small-scale farmers [2-7]. The Tlaxcala Conference introduced a new food regime concept, food sovereignty, and established 11 principles that were integrated into La Via Campesina's Position on Food Sovereignty, presented at the World Food Summit in Rome in November 1996.

The World Food Summit brought together representatives from 185 countries and the European Community with close to 10,000 participants who debated one of the most important issues facing the global community - the imperative of eradicating hunger. In the NGO Response to the Rome Declaration on World Food Security, they presented a six-point plan framed within a rights based 
discourse that challenged transnational capitalist control over the globalized food market and proposed a new framework for ending global hunger.

We propose a new model for achieving food security that calls into question many of the existing assumptions, policies and practices. This model, based on decentralization, challenges the current model, based on a concentration of wealth and power, which now threatens global food security, cultural diversity, and the very ecosystems that sustain life on the planet...Each nation must have the right to food sovereignty to achieve the level of food sufficiency and nutritional quality it considers appropriate without suffering retaliation of any kind [35].

The definition of food sovereignty was further developed in various forums and meetings. The Nyéléni International Forum for Food Sovereignty held in Sélingué, Mali, in 2007 brought together 500 delegates from various organizations in 80 countries who addressed the need for an international plan for resistance that would support political autonomy, and privilege the rights and interests of local producers, distributors and consumers to establish a decision-making process to alleviate hunger and food insecurity. The Nyéléni Declaration articulates the most often cited definition of food sovereignty.

Food sovereignty is the right of peoples to healthy and culturally appropriate food produced through ecologically sound and sustainable methods, and their right to define their own food and agricultural systems. It puts the aspirations and needs of those who produce, distribute and consume food at the heart of food systems and policies rather than the demands of markets and corporations [36].

The concept of food sovereignty was framed within a larger rights discourse and the ability for all people freely and independently to produce their own foods in a political framework that recognized territorial autonomy. Food sovereignty, the delegates stressed, could only operate in in a world where political sovereignty of all peoples was recognized (5], p. 7). This emerging food sovereignty movement challenged the hegemony of transnational capital in the food system, articulating the need to stop viewing food as a "commodity", and demanding that the political rights to produce and distribute food be returned to the producers and consumers [2-7].

This notion of food sovereignty became a uniting call to small-scale farmers and Indigenous peoples throughout the world. While this movement developed in an agrarian-based, Latin American context ([5], p. 1), Indigenous peoples with fishing, hunting, and gathering traditions were able to connect to its underlying philosophy that all nations, including Indigenous nations, have the right to define strategies and policies and develop food systems and practices that reflected their own cultural values around producing, consuming, and distributing food.

Utilizing the term "sovereignty" to apply to this non-state defined food regime seems at odds with Indigenous mobilization as—insofar as sovereignty implies state authority and control—diametrically opposite to Indigenous philosophies that foster relationships with plants, animals, and land based on respect and reciprocity. Some Indigenous scholars have thus contested using the term "sovereignty" for defining the political rights and autonomy Indigenous peoples are seeking.

In Sovereignty Matters, a collection of chapters written by Indigenous scholars who explore notions of sovereignty, cultural self-determination, personal autonomy, and decolonization, Joanne Barker (Lenape) and Taiaiake Alfred (Mohawk) argue that problems arise when Indigenous people use non-Indigenous terms to define their movements, their theories, and their lives ([37], pp. 172-74). In the Western legal sense, sovereignty implies values and objectives that, in many ways, seem to contradict the values and objectives found in most traditional Indigenous philosophies. For example, Indigenous philosophies are grounded in the understanding that humans and the environment are bound in a relationship of reciprocity, respect, and obligations-not coercion and domination ([1], p. 115). Barker contends that, "translating indigenous epistemologies about law, governance, and culture through the discursive rubric of sovereignty was and is problematic. Sovereignty as a discourse is unable 
to capture fully the indigenous meanings, perspectives, and identities, about law, governance, and culture, and thus over time it impacts how these epistemologies and perspectives are represented and understood" ([38], p. 19). Alfred writes, "Western conceptions, with their own philosophical distance from the natural world, have more often reflected kinds of structures of coercion and social power...Indigenous philosophies are premised on the belief that the human relationship to the earth is primarily one of partnership" ([39], p. 45).

Barber and Alfred challenge Indigenous peoples to think about how they understand and relate to the world within a colonial reality and to question the words and terms used to define their actions and existence. For Indigenous people, sovereignty does matter, but it needs to break away from a definition derived from Western political and legal thought and be redefined through and within Indigenous people's own historical and cultural experiences. To indigenize the term sovereignty thus means reframing it within Indigenous people's struggles for autonomy, self-sufficiency, and self-determination rather than within assertions of domination, control, and authority over ancestral homelands.

Indigenous peoples in Canada and the U.S. are exploring ways that Food Sovereignty can be both defined and employed as a concept in creating dialogue and action around the revitalization of Indigenous food practices and ecological knowledges. The Working Group on Indigenous Food Sovereignty (WGIFS), created in 1996, was one of the first Indigenous groups to explore the new concept of Food Sovereignty. Through participation with the British Columbia Food Systems (BCFSN) network, the WGIFS began to articulate ways the concept could be defined and applied to address a wide range of concerns facing regional Indigenous communities as they responded to their own health needs ([40], pp. 101-2).

Coming together in meetings, conferences, and discussion groups, Indigenous elders, traditional harvesters, and community members developed four main principles of Indigenous food sovereignty that frame and guide this new Indigenous Foods Sovereignty movement : (1) Sacred sovereignty: food is a sacred gift from the Creator; (2) Participatory: is a call to action, that people have a responsibility to uphold and nurture healthy and interdependent relationships with the eco-system that provides the land, water, plants, and animals as food; (3) Self-determination: it needs to be placed within a context of Indigenous self-determination with the freedom and ability to respond to community needs around food; (4) Policy: provides a restorative framework for reconciling Indigenous food and cultural values with colonial laws and policies ([40], pp. 100-1; [41]). ${ }^{1}$

Indigenous cultures are shaped by deep and meaningful relationships to the land, water, plants, and animals that have sustained them which, as WGIF director Dawn Morrison asserts, is antithetical to the relationship that Western society has with the environment. While Indigenous communities are distinct, making it impossible to define food sovereignty in a way that reflects all of their realities, Morrison says they are united by eco-philosophical principles that have guided their interactions with the environment and the non-human world that has informed their food systems. She writes,

The Indigenous eco-philosophy that underlies the ability of Indigenous peoples to maintain dignified relationships to the land and food system is in sharp contrast to the Eurocentric belief, inherent in the worldview proposed by European philosopher Rene Descartes, that humans are to dominate and control nature, and therefore seek to "manage" the land that provides us with our food. Indigenous eco-philosophy reinforces belief that humans do not manage land, but instead can only manage our behaviours in relation to it ([40], p. 99).

Indigenous food sovereignty weaves together the theoretical and analytical strands that many Indigenous scholars such as Alfred, Corntassel, Kimmerer and others have explicated regarding Indigenous peoples' relationship to the natural world that was weakened by colonialism, neoliberalism, displacement and capitalism. Thus, Indigenous food sovereignty is defined within a restorative 
context that works to nurture individual and community health by repairing and fostering these healthy relationships.

Placed within a context of self-determination, Indigenous food sovereignty as a concept aligns with principles developed by Cherokee scholar Jeff Corntassel in his notion of "sustainable self-determination". Corntassel positions responsibilities and relationships at the core of Indigenous self-determination. In order to decolonize, he contends, Indigenous peoples need to direct change from within and through action, change, strategies, and policies working toward becoming "sustainable" self-determining nations. Corntassel maintains that "the existing rights discourse can only take indigenous peoples so far" through its emphasis on Settler state political and legal recognition of Indigenous rights, which ignores the cultural responsibilities and relationships -Indigenous peoples have with the land, water, plants, and animals that have sustained their cultures ([42], pp. 105-9).

Within a sustainable self-determination framework, emphasis is placed on decolonization and restoration that connects political autonomy, governance, the environment, and community health. For Indigenous people, Corntassel writes, "sustainability is intrinsically linked to the transmission of traditional knowledge and cultural practices to future generations. Without the ability of community members to continuously renew their relationships with the natural world (i.e., gathering medicines, hunting and fishing, basket-making, etc.), indigenous languages, traditional teachings, family structures, and livelihoods of that community are all jeopardized ([42], p. 118).

Corntassel's notion of sustainable self-determination and the WGIF's definition of Indigenous food sovereignty emphasize responsibility, mutuality, kinship, and relationships. Humans and non-humans, Kimmerer writes, are bound to each other "in a reciprocal relationship" that creates duties and responsibilities for both in what she defines as "cultures of reciprocity." "Just as all beings have a duty to me, I have a duty to them", Kimmerer writes. "If an animal gives its life to feed me, I am in turn bound to support its life. If I receive a stream's gift of pure water, then I am responsible for returning a gift in kind. An integral part of a human's education is to know those duties and how to perform them" ([1], p. 115). The human-ecosystem relationship is characterized as one of reciprocity and respect where humans do not control nature but live in harmony with it. Restoring the health of Indigenous communities means restoring the health of the land. Or, as Kimmerer so aptly states, "We restore the land and the land restores us" ([1], p. 336).

In Eating the Landscape, Indigenous ethnobotanist Enrique Salmón weaves his historical and cultural knowledge into a tapestry of understanding Indigenous environmental stewardship and the ancestral relationship Indigenous peoples have with the world around them. Salmón's identity was grounded in what he calls "an encoded library of cultural and ecological knowledge" that united his relatives through the foods they ate and the recipes they shared, binding them to the landscape in a familial relationship of respect:

The knowledge I learned from my family was one aspect of a trove of culturally accumulated ecological knowledge. When they introduced me to individual plants, they also introduced my kinship to the plants and to the land from where they and we emerged. They were introducing me to my relatives. Through this way of knowing, especially with regard to kinship, I realized a comfort and a sense of security that I was bound to everything around me in a reciprocal relationship ([43], p. 2).

The Inuit in northern Alaska have a saying, "I am what I am because of what I eat" ([12], p. 199). Studies of the Indigenous whaling nations in the Arctic demonstrate how traditional foods, especially whales, have social, cultural, spiritual, and psychological significance. While a high value is placed on whales as a healthy food source, the tradition of whaling maintains community solidarity and collective security through the communal hunts and the processing, distributing, and consuming of whale products by community members. Whaling serves to link the Inuit materially, symbolically, and spiritually to their cultural heritage and ancestral knowledge [12].

Within Indigenous cosmologies, Sam Grey and Raj Patel assert, both landscapes and foodscapes occupy a simultaneously physical, spiritual, and social geography and just "as kinship is not restricted 
to consanguine human beings, sacredness does not merely congeal in particular places, but is a quality of the totality of the natural world-including all of the life-forms that provide sustenance and frame trade networks. Thus, food can be seen as the most direct manifestation of the relationships between Indigenous peoples and homelands, and it consequently occupies a central space in traditional thought" ([44], p. 436).

\section{Hishuk'ish Tsawalk, "Everything is One"}

I end this article with a brief discussion of my people the Nuu-chah-nulth-aht (Nuu-chah-nulth people) on the west coast of Vancouver Island in British Columbia, Canada, whose efforts to restore respectful and meaningful relationships with their environment are situated within this notion of Indigenous food sovereignty. The Nuu-chah-nulth-aht are actively engaging decolonization and sustainable self-determination through reinstatement of authority over our ha-huulhi (ancestral territory) and through the development of strategies and implementation of policies aimed at the sustainable production and consumption of traditional foods through an ecologically sound food system that honors our sacred relationships to land, water, plants and all living things. Embodied in Nuu-chah-nulth philosophies of hishuk'ish tsawalk, (everything is one), uu-a-thluk (taking care of), and iisaak, (respect) is the understanding that we must honor the wisdom and values of ancestral knowledge in maintaining responsible and respectful relationships with the natural world.

The Nuu-chah-nulth, ${ }^{2}$ a word meaning, "all along the mountains and sea", are 15 independent communities, united through language, culture, and territory, In 1979, 14 communities came together to form the united political body the Nuu-chah-nulth Tribal Council (NTC). ${ }^{3}$ Nuu-chah-nulth autonomy over our marine space is crucial to our survival as a people. Before the mamalhn' $i$ (non-Indigenous people) arrived on the B.C. coastline, the Nuu-chah-nulth-aht derived most of their subsistence from the marine space with salmon being at the core of our identity. Through annual First Salmon Ceremonies, the spirit of the salmon is honored through songs and prayers that demonstrate respect for giving its physical form to feed our communities. Colonial encounters severed our sacred relationship to the salmon and through the years we have continually fought in the political and legal arenas to have our right to harvest salmon recognized and affirmed. In November 2009, after a decade of legal battling, the Nuu-chah-nulth successfully fought and won the legal right to control their fisheries. On hearing the decision, NTC President Cliff Atleo Sr. declared, "Today this decision confirms what we've known all along. We have been stewards of our ocean resources for hundreds of generations. And the government of Canada was wrong to push us aside in their attempts to prohibit our access to the sea resources our people depend upon" [45].

In March 2005, the Nuu-chah-nulth launched $u u-a-t h l u k$, an aquatic resource management organization administered through the NTC. The vision of $u$ u-a-thluk is to "take care of" the ha-huulhi in a way that is consistent with Nuu-chah-nulth values and principles, a responsibility given to our people through n'aas, our Creator. The organization is guided by a Council of Ha'wiih (hereditary chiefs) who meet three times a year to provide guidance and direction through sharing their ecological knowledge and ancestral wisdom with the staff and seasonal interns [46]. This philosophy of marine management is consistent with efforts to become sustainable self-determining nations and reinforces the ruling authority of our $h a^{\prime}$ wilth patuk $h a^{\prime}$ wiih (traditional governance).

Nuu-chah-nulth-aht are raised with the understanding of iisaak (respect), which applies to all life-forms as well as the land and water. Iisaak, at its most basic understanding, teaches that all life forms are held in equal esteem. Our relationships to the plants and animals that give themselves as food derives from iisaak, which enforces sustainability and places sanctions on those who are stingy

2 Also known as Nootka and Nutka.

This political body was created out of the previous collectivity known as the Westcoast Allied Tribes formed in 1958, which changed its name to the West Coast District Society of Indian Chiefs in 1973 and was officially incorporated as the Nuu-chah-nulth Tribal Council in 1979. 
or wasteful ([47], pp. 17-18; [48], p. 1279). The principle of iisaak is embedded within an overarching philosophy of hishuk'ish tsawalk, everything is one.

Within the Nuu-chah-nulth worldview, Nuu-chah-nulth chief Umeek explains, "the universe is regarded as a network of relationships" ([47], p. 118). Hishuk'ish tsawalk represents the unity of the physical and metaphysical in a relationship embodied in the principle of iisaak. This philosophy connects people, animals, plants, and the natural and the supernatural (spiritual) realms in a seamless and interconnected web of life where all life forms are revered and worthy of mutual respect. The land, water, animals and plants are regarded as your kinfolk, not as a commodity that can be exploited ([47], p. 10; [48], p. 1279; [49], p. 540). The stewardship of our homelands was embedded in this philosophy, and this is what we are striving to revitalize.

Indigenous food sovereignty is positioned within a restorative framework that places responsibility and action on individuals and communities to repair and strengthen relationships to ancestral homelands weakened by colonialism, globalization, and neoliberal policies. Through a process of decolonization and sustainable self-determination, the Nuu-chah-nulth-aht are actively restoring and strengthening the spiritual and cultural bonds with their ha-huulhi (ancestral homelands) through the development of environmental and food policies that are grounded in principles of respect and responsibility. It is time, Kimmerer writes, that Indigenous peoples honor the responsibilities they have to the nonhuman world and acknowledge what has been given and was has been taken in this "moral covenant of reciprocity." She writes,

"It's our turn now, long overdue. Let us hold a giveaway for Mother Earth, spread our blankets out for her and pile them high with gifts of our own making...Whatever our gift, we are called to give it and to dance for the renewal of the world. In return for the privilege of breath." ([1], p. 384).

Conflicts of Interest: The author declares no conflict of interest.

\section{References}

1. Kimmerer Robin Wall. Braiding Sweetgrass. Indigenous Wisdom, Scientific Knowledge, and the Teachings of Plants. Minneapolis: Milkweed Editions, 2013.

2. Raj Patel. "Food sovereignty." The Journal of Peasant Studies 36 (2009): 663-706. [CrossRef]

3. Peter Rosset. "Food Sovereignty and the Contemporary Food Crisis." Development 51 (2008): $460-63$. [CrossRef]

4. Hannah Wittman, Annette Aurélie Desmarais, and Nettie Wiebe. “The Origins and Potential of Food Sovereignty." In Food Sovereignty. Reconnecting Food, Nature and Community. Edited by Hannah Kay Wittman, Annette Aurelie Desmarais and Nettie Wiebe. Nova Scotia and Winnipeg: Fernwood Publishing, 2010.

5. Amy Trauger. "Putting Food Sovereignty in Place." In Food Sovereignty in International Context. Discourse, Politics and Practice of Place. Edited by Amy Trauger. New York: Routledge, 2015.

6. La Via Campesina. “The international peasant's voice." Available online: http://viacampesina.org/en/ index.php/organisation-mainmenu-44 (accessed on 5 January 2016).

7. Lucy Jarosz. “Comparing Food Sovereignty, Food Security Discourses.” Dialogues in Human Geography 4 (2014): 168-81. [CrossRef]

8. McMichael Philip. "The power of food." Agriculture and Human Values 17 (2000): 21-33.

9. Teresa Evans-Campbell. "Historical Trauma in American Indian/Native Alaska Communities: A Multilevel Framework for Exploring Impacts on Individuals, Families, and Communities." Journal of Interpersonal Violence 23 (2008): 316-38. [CrossRef] [PubMed]

10. Michael Gracey, and Malcolm King. "Indigenous Health, Part 1: Determinants and Disease Patterns." The Lancet 374 (2009): 65-75. [CrossRef]

11. David Wallace Adams. Education for Extinction. American Indians and the Boarding School Experience, 1875-1928. Lawrence: University of Kansas Press, 1995.

12. Charlotte Coté. Spirits of Our Whaling Ancestors: Revitalizing Makah and Nuu-Chah-Nulth Traditions. Seattle: University of Washington Press, 2010. 
13. Malcolm King, Alexandra Smith, and Michael Gracey. "Indigenous Health, Part 2: The Underlying Causes of the Health Gap." The Lancet 374 (2009): 76-86. [CrossRef]

14. Nuu-chah-nulth Tribal Council. Indian Residential Schools: The Nuuchah-Nulth Experience. Port Alberni: Nuu-chah-nulth Tribal Council, 1996.

15. James Rodger Miller. Shingwuak's Vision: A History of Native Residential Schools. Toronto: University of Toronto Press, 1996.

16. Jean Barman, Yvonne Hébert, and Don McCaskill. Indian Education in Canada, Vol. 1: The Legacy. Vancouver: University of British Columbia Press, 1986.

17. Jon Reyner, and Jeanne Eder. American Indian Education: A History. Norman: University of Oklahoma Press, 2004.

18. Dian Million. "Felt Theory An Indigenous Feminist Approach to Affect and History." Wicazo Sa Review 24 (2009): 53-76. [CrossRef]

19. Truth and Reconciliation Website. Available online: http://www.trc.ca/websites/trcinstitution/index.php? $p=3$ (accessed on 5 January 2016).

20. Ian Mosby. "Administering Colonial Science: Nutrition Research and Human Biomedical Experimentation in Aboriginal Communities and Residential Schools, 1942-1952." Social History 46 (2013): 145-72.

21. "Shayne Morrow Canada Must Apologize for Nutritional Experiments at Residential School: Tseshaht." Ha-shilth-sa, 17 July 2013. Available online: http:/ / www.hashilthsa.com/news/2013-07-17/canada-mustapologize-nutritional-experiments-residential-school-tseshaht (accessed on 11 June 2014).

22. Valarie Blue Bird Jernigan, Bonnie Duran, David Ahn, and Marilyn Winkleby. "Changing Patterns in Health Behaviors and Risk Factors Related to Cardiovascular Disease Among American Indians and Alaska Natives." American Journal of Public Health 100 (2010): 677-83. [CrossRef] [PubMed]

23. "An Overview of Aboriginal Health in Canada." National Collaborating Centre for Aboriginal Health, 18 July 2013. Available online: http://www.nccah-ccnsa.ca/en/publications.aspx?sortcode=2.8.10\& publication=101 (accessed on 15 November 2015).

24. Kelly J. Acton, Nilka Rios Burrows, Kelly Moore, Linda Querec, Linda S. Geiss, and Michael M. Engelgau. "Trends in Diabetes Prevalence among American Indian and Alaska Native Children, Adolescents, and Young Adults." American Journal of Public Health 92 (2002): 1485-90. [CrossRef] [PubMed]

25. Taiaiake Alfred, and Jeff Corntassel. "Being Indigenous. Resurgences against Contemporary Colonialism." Government and Opposition 40 (2005): 597-614. [CrossRef]

26. Also see, Taiaiake Alfred. Peace, Power, Righteousness. An Indigenous Manifesto, rev. ed. Oxford: Oxford University Press, 2009.

27. Angela Cavender Wilson. "Reclaiming our Humanity. Decolonization and the Recovery of Indigenous Knowledge." In Indigenizing the Academy. Transforming Scholarship and Empowering Communities. Edited by Devon Abbot Mihesuah and Angela Cavender Wilson. Lincoln: University of Nebraska Press, 2004.

28. Linda Tuhiwai Smith. Decolonizing Methodologies. Research and Indigenous Peoples, 2nd ed. London: Zed Books, 2012.

29. United Nations. “United Nations Declaration on the Rights of Indigenous Peoples." 2007. Available online: http:/ / www.un.org/esa/socdev/unpfii/documents/DRIPS_en.pdf (accessed on 2 November 2015).

30. Jeff Corntassel. "Practicing Sustainable Self-Determination." The Brown Journal of World Affairs 18 (2012): 151-62.

31. Kristin Moe. "Mother Earth at the Heart of It." Yes! 66 (2013): 31-32.

32. "Idle No More website." Available online: http:/ / www.idlenomore.ca/vision (accessed on 11 October 2012).

33. Terry Wotherspoon, and John Hansen. "The ‘Idle No More' Movement: Paradoxes of First Nations Inclusion in the Canadian Context." Social Inclusion 1 (2013): 21-36. [CrossRef]

34. Waziyatawin. "The Paradox of Indigenous Resurgence at the End of Empire." Decolonization: Indigeneity, Education \& Society 1 (2012): 68-85.

35. Statement by the NGO Forum to the World Food Summit. "World Food Summit." 13-17 November 1996. Available online: http://www.fao.org/wfs/ (accessed on 25 September 2015).

36. Mali Sélingué. “Declaration of Nyéléni." 27 February 2007. Available online: http://nyeleni.org/spip.php? article290 (accessed on 5 January 2016).

37. Charlotte Coté. "Sovereignty Matters. Locations of Contestation and Possibility in Indigenous Struggles for Self-Determination." American Indian Culture and Research Journal 31 (2007): 172-74. 
38. Joanne Barker. "For Whom Sovereignty Matters." In Sovereignty Matters. Locations of Contestation and Possibility in Indigenous Struggles for Self-Determination. Lincoln and London: University of Nebraska Press, 2005.

39. Taiaiake Alfred. "Sovereignty." In Sovereignty Matters. Locations of Contestation and Possibility in Indigenous Struggles for Self-Determination. Edited by Joanne Barker. Lincoln and London: University of Nebraska Press, 2005.

40. Dawn Morrison. "Indigenous Food Sovereignty. A Model for Social Learning." In Food Sovereignty in Canada. Creating Just and Sustainable Food Systems. Edited by Hannah Wittman, Annette Aurélie Desmarais and Nettie Wiebe. Winnipeg and Nova Scotia: Fernwood Publishing, 2011.

41. Indigenous Food Systems Network Website. Available online: http://www.indigenousfoodsystems.org (accessed on 3 November 2015).

42. Jeff Corntassel. "Toward Sustainable Self-Determination: Rethinking the Contemporary Indigenous-Rights Discourse." Alternatives 33 (2008): 105-32. [CrossRef]

43. Enrique Salmón. Eating the Landscape: American Indian Stories of Food, Identity, and Resilience. Tucson: University of Arizona Press, 2012.

44. Sam Grey, and Raj Patel. "Food Sovereignty as Decolonization: Some Contributions from Indigenous Movements to Food Systems and Development Politics." Agriculture \& Human Values 32 (2015): 431-44. [CrossRef]

45. Lloyd Dohla. "Nuu-chah-nulth Celebrate Landmark Decision." First Nations Drum, 27 November 2009. Available online: http://www.firstnationsdrum.com/2009/11/nuu-chah-nulth-celebrate-landmarkfisheries-decision/ (accessed on 5 January 2016).

46. Uu-a-thluk Website. Available online: http://uuathluk.ca/wordpress/\# (accessed on 2 October 2015).

47. Umeek E. Richard Atleo. Tsawalk. A Nuu-Chah-Nulth Worldview. Vancouver: University of British Columbia Press, 2004.

48. Nancy Turner, Marianne Boelscher Ignace, and Ronald Ignace. "Traditional Ecological Knowledge and Wisdom of Aboriginal Peoples in British Columbia." Ecological Applications 10 (2000): 1275-87. [CrossRef]

49. Christopher M. Raymond, Gerald G. Singh, Karina Benessaiah, Joanna R. Bernhardt, Jordan Levine, Harry Nelson, Nancy J. Turner, Bryan Norton, Jordan Tam, and Kai M. A. Chan. "Ecosystem Services and Beyond: Using Multiple Metaphors to Understand Human-Environment Relationships." BioScience 63 (2013): 536-45.

(C) 2016 by the author; licensee MDPI, Basel, Switzerland. This article is an open access article distributed under the terms and conditions of the Creative Commons Attribution (CC-BY) license (http://creativecommons.org/licenses/by/4.0/). 